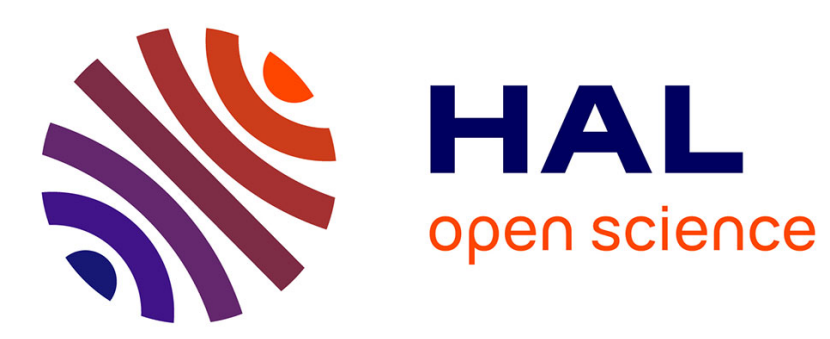

\title{
Isolation of Indonesian Cananga oil by instantaneous controlled pressure drop
}

Magdalena Kristiawan, Vaclav Sobolik, Karim Allaf

\section{To cite this version:}

Magdalena Kristiawan, Vaclav Sobolik, Karim Allaf. Isolation of Indonesian Cananga oil by instantaneous controlled pressure drop. Journal of Essential Oil Research, 2008, 20 (2), pp.135-146. 10.1080/10412905.2008.9699975 . hal-02655771

\section{HAL Id: hal-02655771 https://hal.inrae.fr/hal-02655771}

Submitted on 29 May 2020

HAL is a multi-disciplinary open access archive for the deposit and dissemination of scientific research documents, whether they are published or not. The documents may come from teaching and research institutions in France or abroad, or from public or private research centers.
L'archive ouverte pluridisciplinaire HAL, est destinée au dépôt et à la diffusion de documents scientifiques de niveau recherche, publiés ou non, émanant des établissements d'enseignement et de recherche français ou étrangers, des laboratoires publics ou privés. 


\title{
Isolation of Indonesian Cananga Oil by Instantaneous Controlled Pressure Drop
}

\author{
Magdalena Kristiawan, Vaclav Sobolik and Karim Allaf, \\ University of La Rochelle, Pole Sciences, Laboratory Mastering of Agro-Industrial Technologies, Avenue Michel Crépeau, \\ 17042 La Rochelle, France
}

\begin{abstract}
The isolation of cananga oil by a new process, Instantaneous Controlled Pressure Drop (DIC), was investigated. This process consists in heating the dry cananga (Cananga odorata Hook. fil. et Thomson, forma macrophylla) flowers for a short time period by steam, followed by an abrupt pressure drop into a vacuum (about $5 \mathrm{kPa}$ ). This pressure drop provokes auto-vaporization of the volatile compounds, puffing of flowers, breaking of cell walls and cooling. The effect of the process parameters, namely number of DIC cycles (1-9), saturated steam pressure (0.2-0.6 MPa), and heating time $(0.5-20 \mathrm{~min})$ on the oil yield and oil composition was examined. The results indicated a significant increase of oil yield with increasing processing pressure and number of DIC cycles, however the total heating time was not a significant parameter. The DIC oil was compared with the oil obtained using steam distillation (SD). DIC exhibited better results than SD concerning rapidity (4 min versus $24 \mathrm{~h}$ ), oil yield (2.74\% versus $2.60 \%$ ) and also oil quality.
\end{abstract}

\section{Key Word Index}

Cananga odorata f. macrophylla, Annonaceae, cananga oil, instantaneous controlled pressure drop, essential oil composition, $\beta$-caryophyllene, caryophyllene oxide.

\section{Introduction}

Cananga odorata Hook. fil. et Thomson is one of the most useful aromatic plants. Plants of the genus Cananga are rich in alkaloids and terpenoids which have promising pharmacological and therapeutic effects $(1,2)$. Hsieh et al. (3) reported potent cytotoxicity of 8 alkaloids isolated from methanolic extract of C. odorata against hepatocarcinoma. Commercially, the flowers of C. odorata provide several grades of an essential oil to the fragrance industry, including perfumes, soaps, colognes, skin lotions and other cosmetics. In food manufacturing, this oil is employed as a minor flavor component in beverages, ice cream, candy, baked goods and chewing gum (4-7).

The essential oil of $C$. odorata is mostly obtained by steam distillation of fresh flowers (4). The quality of oil is assessed according to the chemical composition and fragrance. Modern volatile concentrate extraction techniques such as supercritical fluid $\mathrm{CO}_{2}$ extraction is a relative fast process providing a high quality product. Nevertheless, the high-pressure equipment $(\sim 10-30 \mathrm{MPa})$ makes this process expensive and difficult to handle (8). Moreover, this process is not selective for polar compounds and extracts also culticular waxes and lipids as do other extraction processes (9).

The need of a more rational technique for the isolating high quality essential oils led to the development of a rapid and environmentally friendly isolation process: Instantaneous Controlled Pressure Drop (DIC) (10). DIC process is based on the thermo-mechanical effects induced by subjecting a raw material for a short time period to saturated steam (about 0.1 to $0.6 \mathrm{MPa}$ according to the product), followed by an abrupt pressure drop towards a vacuum (about $5 \mathrm{kPa}$ ). This abrupt pressure drop $(\Delta p / \Delta t>0.5 \mathrm{MPa} / \mathrm{s})$ provokes simultaneously auto-vaporization of volatile compounds, instantaneous cooling of the products which stops thermal degradation, expansion of the internal structure and eventually implies rupture of the cell walls. The rate of mass transfer processes is high due to the expanded porous and broken structure.

The optimum processing parameters of DIC isolation technology are specific for each aromatic plant. Rezzoug et al. (10) reported that in the case of isolation of rosemary oil, one DIC cycle during $10 \mathrm{~min}$ at a low pressure $(0.1 \mathrm{MPa})$ had an isolation efficiency of $95.8 \%$. On the other hand, more severe DIC conditions were needed for the isolation of an oil from juniper berries. Mellouk et al. (11) needed two DIC cycles at a pressure of $0.6 \mathrm{MPa}$ to isolate within $150 \mathrm{~s} 95 \%$ of the oil as against $12 \mathrm{~h}$ for steam distillation.

The aim of this work is to study the effect the DIC parameters on the isolation of the essential oil from dry Indonesian cananga (C. odorataf. macrophylla) flowers. The oil separated 
from the DIC condensate was weighed and its composition analyzed using gas chromatography with mass spectrometry. The volatiles extracted from the residual flowers were also analyzed. The results were compared with the steam-distilled oil and the reference volatiles in the extract obtained from dry flowers using chloroform extraction. In the first paper of the series devoted to dry cananga flowers, we studied the isolation of an oil using steam distillation and extracts using organic solvents with different polarities (12).

\section{Experimental}

The analysis of DIC isolated oil and extract of the residual flowers were carried out according to the protocol shown in Figure 1. The effects of 3 DIC parameters were studied. The steam pressure was varied between 0.2 and $0.6 \mathrm{MPa}$, the total heating time from 0.5 to $20 \mathrm{~min}$ and the number of DIC cycles between 1 and 9. More experimental details can be found in (13).

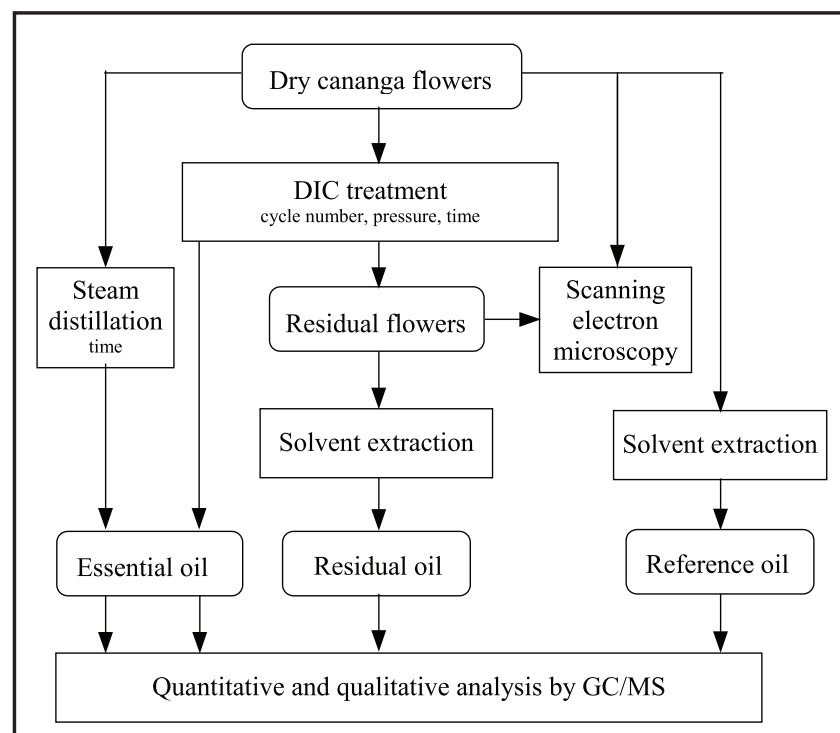

Figure 1. Protocol for the evaluation of DIC performance on cananga oil isolation.

Materials: Fully mature cananga flowers (Cananga odorata f. macrophylla) were picked at blossom in Lawang, East Java (Indonesia). The flowers were air-dried to a final moisture content of $10.2 \%$ dry basis.

External standard solutions at $0.2,0.6,1.2,2,3,5 \mathrm{mg} /$ $\mathrm{mL}$ of methyl nonadecanoate (puriss. p.a. standard for GC, Fluka, Germany) in chloroform (p.a., Carlo Erba, France) were prepared for GC/MS analysis. $\mathrm{NaCl}$ (purum p.a., Fluka, Germany), anhydrous $\mathrm{Na}_{2} \mathrm{SO}_{4}$ (p.a., Fischer Chemicals, UK) and chloroform (p.a.) were used as demulsifier, drying agent and solvent, respectively, in the liquid-liquid extraction step of the aqueous extracts. Hexane (p.a., Carlo Erba, France) was used as an oil-fixation layer in the SD method.

\section{Isolation methods}

DIC apparatus and procedure: The schematic diagram of the DIC apparatus used for the essential oil isolation is shown in Figure 2. A mass of $40 \mathrm{~g}$ of dry cananga flowers was treated in the $6 \mathrm{~L}$ autoclave (1). A layer of $70 \mathrm{~mm}$ of flowers was placed in a container with a diameter of $110 \mathrm{~mm}$. The container was made of a perforated steel sheet. The autoclave was connected

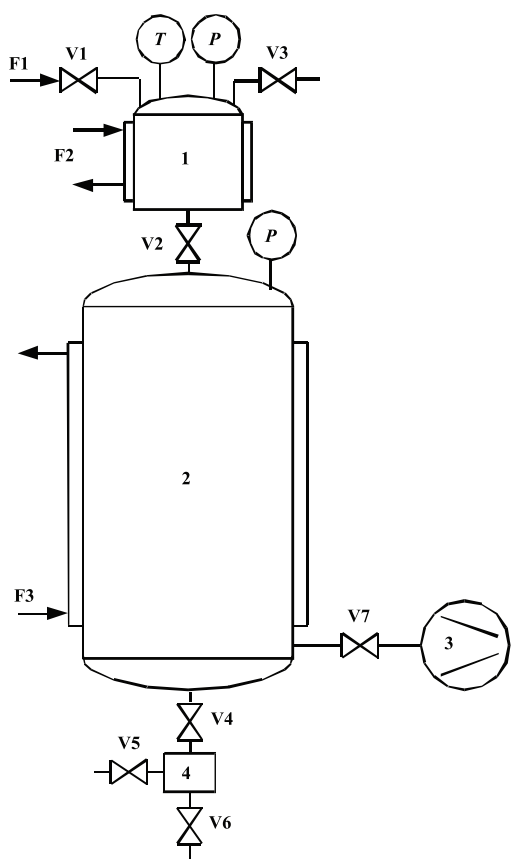

Figure 2. Schematic diagram of the instantaneous controlled pressure drop apparatus. (1) autoclave with heating jacket; (V2) rapid valve; (2) vacuum tank with cooling water jacket; (3) vacuum pump; (4) extract trap; F1 \& F2 steam flow; F3 cooling water flow.

via the $80 \mathrm{~mm}$ spherical valve (V2) to a vacuum tank (3) with a volume of $285 \mathrm{~L}$. By opening this valve, the flowers were exposed to an initial vacuum which allowed a better diffusion of the heating fluid. After closing the valve (V2), saturated steam was injected into the autoclave and a fixed pressure was maintained for a predetermined time. After this thermal treatment the steam was cut and the valve (2) was opened rapidly (in less than $200 \mathrm{~ms}$ ) which resulted in an abrupt pressure drop towards a vacuum. The pressure in the vacuum tank was maintained by a water ring pump (3) at about $5 \mathrm{kPa}$. The vapor created in the cananga flowers by auto-vaporization induces mechanical stresses which deform or even break the cells. This effect depends on the rheological properties of the plants which are function of humidity and temperature. The adiabatic auto-vaporization cools the residual product from $120-160^{\circ} \mathrm{C}$ (depending on the steam pressure) to about $30-35^{\circ} \mathrm{C}$. The next step is either repetition of the DIC cycle (the steam treatment followed by the pressure drop) or restoration of the atmospheric pressure by opening a vent (V3). The corresponding pressure and temperature histories are shown in Figure 3.

In multi-cycle DIC process, steam is injected after the stage (f) and the pressure is controlled for the time (d). It means that $n$ cycles contain $n$ repetition of the stages (c), (d), (e) and (f). The last cycle is finished by the stage (g). The total heat- 
ing time is the heating time of $n$ cycles. The flowers require a certain time to reach the steam temperature. The difference depends on the heat transfer, especially on the height of flowers layer. Louka (14) showed that the initial vacuum significantly increases the heat transfer between the steam and material. A uniform temperature was reached in the $150 \mathrm{~mm}$ thick layer of potatoes dices in about $8 \mathrm{~s}$ whereas a time of $45 \mathrm{~s}$ was needed without initial vacuum. The initial vacuum increases the speed of the vapor propagation and diminishes the amount of insulating air. The presence of air also diminishes the partial pressure of the steam. After the DIC treatment, the condensate (oil-in-water emulsion) was recovered from an extract trap (4) situated at the bottom of the vacuum tank (2). The tank walls were washed up with condensates resulting from eight cycles carried out without flower charge.

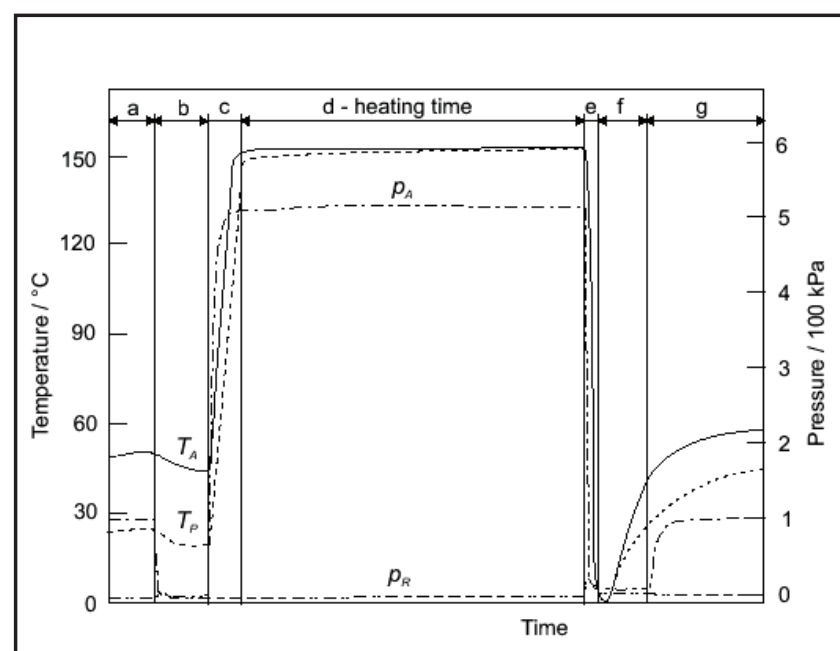

Figure 3. Temperature and pressure history of DIC cycle. $T^{A}$ temperature in autoclave, $T^{P}$ temperature of product, $\mathrm{p}^{\mathrm{A}}$ pressure in autoclave, $\mathrm{p}^{\mathrm{R}}$ pressure in reservoir. (a) sample at atmospheric pressure; (b) initial vacuum; (c) saturated steam injection to reach the selected pressure ; (d) constant temperature corresponding to saturated steam pressure; (e) abrupt pressure drop towards vacuum; (f) vacuum; $(g)$ releasing to the atmospheric pressure.

Steam distillation of flowers: Steam distillation was carried out with a Pignat P3734 laboratory apparatus. A packed bed of $80 \mathrm{~g}$ of dry cananga flowers was placed on a stainless steel grill fixed above a distillation vessel containing $2 \mathrm{~L}$ of water. Electric heating of the water produced $2.5 \mathrm{~kg} / \mathrm{h}$ steam which in turn passed through the flower bed where it evaporated and carried away the essential oil. The vapors were condensed in a condenser and collected in a receiver vessel. At the beginning the receiver was filled with $1 \mathrm{~L}$ of water and $150 \mathrm{~mL}$ of hexane. Hexane was used as an oil-fixation layer, minimizing the dissolution of oil components (mainly the polar compounds) in the aqueous phase and thus avoiding the thermal degradation owing to recycling of the aqueous phase into the distillation vessel. A cooling tap water system around the receiver vessel cooled the distillate from $100-25^{\circ} \mathrm{C}$ in order to avoid the loss of volatile compounds. During the isolation process, the excess of water in the receiver vessel was recycled into the distillation vessel in order to restore the evaporated water. When the distillation time (processing time) had elapsed, the hexane phase, which was very rich in oil, was separated from the aqueous phase. Sodium sulphate (anhydrous) was added to the hexane solution in order to remove moisture. Also the aqueous phase was subjected to liquid-liquid extraction in order to isolate the secondary oil. Finally, the hexane solution and the secondary oil were mixed and concentrated under a vacuum in a rotary-evaporator to obtain the whole oil. The dried samples were diluted with chloroform to $20 \mathrm{~mL}$ and stored in the dark at $4^{\circ} \mathrm{C}$ prior to analysis by $\mathrm{GC} / \mathrm{MS}$.

Liquid-liquid extraction of aqueous extracts: Prior to analysis, the critical stage was the separation of the oil from the condensate obtained after steam distillation and DIC isolation. The condensate was extracted three times using a separator funnel with chloroform and $\mathrm{NaCl}$ to facilitate the emulsion breakdown. Sodium sulphate (anhydrous) was added to remove moisture and the organic phase was then concentrated under a vacuum in a rotary-evaporator at $30^{\circ} \mathrm{C}$. Each dried sample was diluted with chloroform to $20 \mathrm{~mL}$ and stored in the dark at $4^{\circ} \mathrm{C}$ prior to analysis of the oil yield and composition by GC/MS.

Solvent extraction of flowers: The Randall technique was used for the solvent extraction of reference and residual oils (15). The reference oil was obtained in the following way. Dry cananga flowers $(4 \mathrm{~g})$ were extracted with $80 \mathrm{~mL}$ of organic solvent heated to boiling point during $6 \mathrm{~h}$ using a Velp Scientifica SER 148 extractor. Our preliminary investigation showed that $95 \%$ of the volatiles could be extracted by chloroform from raw material in $6 \mathrm{~h}$ (12). The solution was then concentrated under a vacuum in a rotary-evaporator at $30^{\circ} \mathrm{C}$. Each dried sample was diluted with chloroform to $20 \mathrm{~mL}$ and stored in the dark at $4^{\circ} \mathrm{C}$ prior to analysis by GC/MS.

The residual oil was extracted from the residual flowers (the flowers after DIC treatment) with chloroform and analyzed in the same manner as the reference oil.

\section{Analytical methods}

Yield and availability: Yield of DIC oil, steam distilled oil, reference oil and residual oil was based on dry plant mass as

$$
\text { oil yield }=\frac{\text { oil mass }}{\text { mass of dry flowers }}
$$

where the oil mass was computed from GC peak area of all volatile molecules (16). DIC and steam distilled oils mean the volatiles molecules presented in the DIC and steam distillation condensates, respectively. Reference oil denotes the volatile molecules isolated from non-treated dry flowers by chloroform extraction. Residual oil means the volatile molecules isolated from DIC treated flowers using the same solvent.

The yield in respect to a compound content was calculated as

compound yield $=$

oil yield $x$ mass fraction of compound in oil , 
where the fraction of a compound in oil $(w / w)$ is the compound content in the oil determined by GC/MS.

The sum of the DIC oil and residual oil was often greater than the amount of the reference oil. The DIC treatment breaks the cellular walls and makes the compounds more available. This effect is described by the notion availability. The availability of the compound $i$ in the residual oil is defined by the following expression

$A_{i R}=\frac{\text { yield of compound } i \text { in residual oil }}{\text { yield of compound } i \text { in reference oil }}$

The total availability of the volatile $i$ is calculated as

$$
A_{i}=\frac{\text { yield of compound } i \text { in DIC oil and residual oil }}{\text { yield of compound } i \text { in reference oil }},
$$

Gas chromatography/mass spectrometry: The volatile molecules were analyzed by gas chromatography coupled to mass spectrometry (GC/MS). We used this method for a comparative study of DIC isolation and steam distillation even if GC/FID is widely used for quantitative analysis of essential oil. A Varian computerized system comprising a 3900 gas chromatograph equipped with a fused-silica-capillary column with a non-polar stationary phase poly (dimethylsiloxane) CP-Sil 8 (30 $\mathrm{m} \times 0.25$ $\mathrm{mm} \times 0.25 \mu \mathrm{m}$ film thickness) was connected to a $2100 \mathrm{~T}$ mass spectrometer. The measurements were performed under the following conditions: carrier gas He; flow rate $1 \mathrm{~mL} / \mathrm{min}$; split 1:100; injection volume $0.1 \mu \mathrm{L}$; injection temperature $250^{\circ} \mathrm{C}$; the oven temperature was increased from $60-170^{\circ} \mathrm{C}$ at $2.5^{\circ} \mathrm{C} /$ min; from $170-250^{\circ} \mathrm{C}$ at $10^{\circ} \mathrm{C} / \mathrm{min}$ and held at $250^{\circ} \mathrm{C}$ for 5 min. The ionization mode was an electronic impact at $70 \mathrm{eV}$. Mass spectra and reconstructed chromatograms were obtained by automatic scanning in the mass range m/z 30-400 a.m.u at $2.2 \mathrm{scan} / \mathrm{s}$. Identification of the components was achieved by a comparison of their retention indices relative to C8-C32 nalkanes and mass spectral fragmentation patterns with those found in the literature (17-20) and stored in the data bank (Varian NIST MS Database 1998 and Saturn libraries).

A quantitative analysis was performed by the method of peak area normalization without application of response factor corrections. Because of non-availability of authentic standards, all relative response factors were taken as one $(16,21)$. Individual calibration of each constituent with its authentic compounds as external standards can be easily done with simple oils, but it is impossible with more complex oils containing many interesting constituents such as cananga oil. Thus, in the present work, the quantity of oil and their principal components was determined by the external standard method using only one authentic compound, i.e. methyl nonadecanoate. The standard curves were generated by analysis of known concentrations of methyl nonadecanoate dissolved in chloroform. Then the quantification was made with linear calibration curve of the external standard and dilution factor.

Scanning electron microscopy: The flower structure was investigated by scanning electron microscopy. Micrographs of the non-treated and DIC treated flowers were taken with a Jeol 5410 LV SEM.

\section{Results and discussion}

Oil yield: The DIC oil yield as a function of time and number of DIC cycles is shown in Figure 4 for three different pressures. The oil yield increases with increasing total heating time. The increase is considerable in the first $6 \mathrm{~min}$ and then the yield changes only little. The number of DIC cycles has a significant effect on the oil yield. At $0.2 \mathrm{MPa}$, the change in
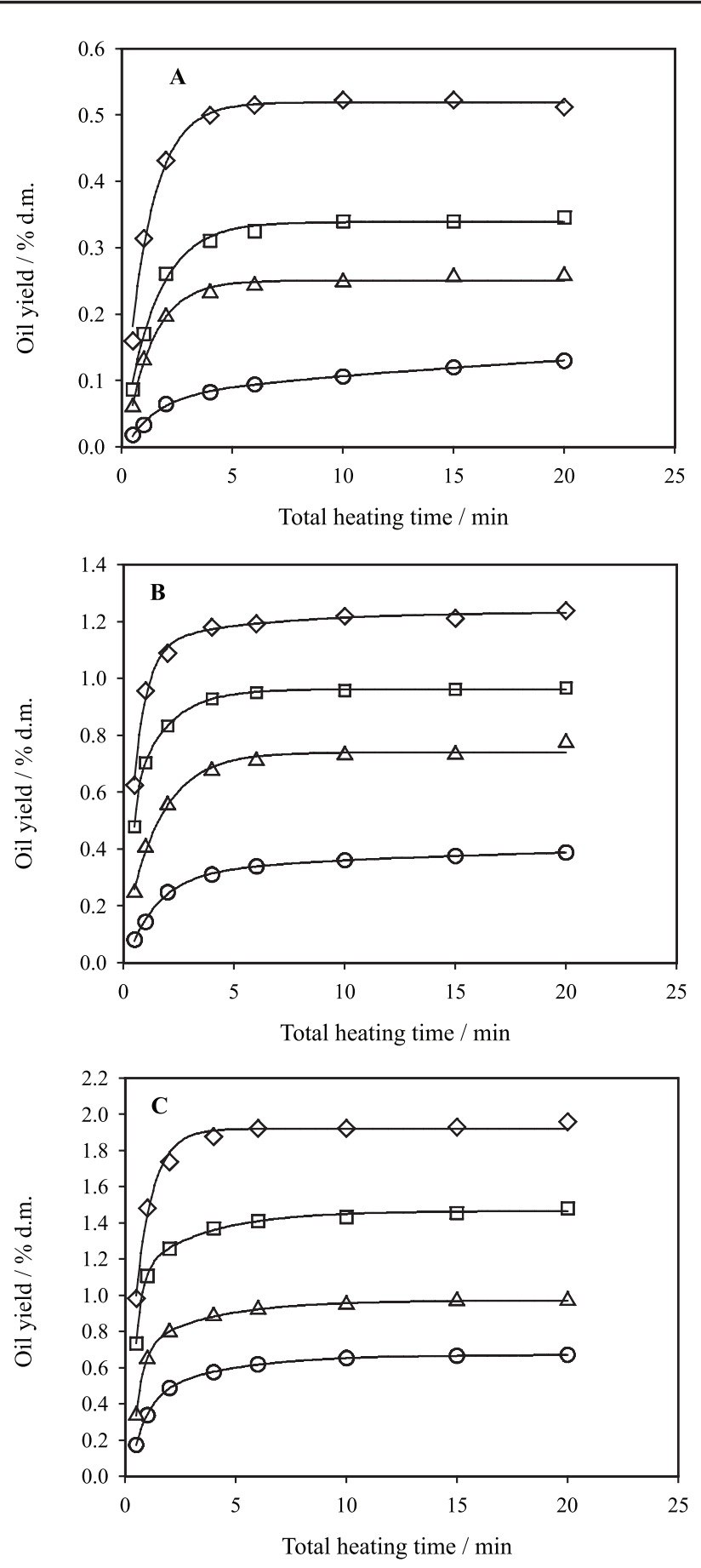

Figure 4. Effect of DIC cycles and total heating time on oil yield at different pressure: $\mathrm{A}-0.2 \mathrm{MPa}, \mathrm{B}-0.4 \mathrm{MPa}, \mathrm{C}-$ $0.6 \mathrm{MPa}$. Number of DIC cycles: $0-1 ; \Delta-2 ; \square-3 ; \diamond-4$. 
cycles from 1 to 4 increases the yield in 6 min from $0.09 \%$ to $0.52 \%$ (see Figure $4 \mathrm{~A}$ ). Evidently, this yield is low in comparison to the yield of steam distillation of fresh flowers in $24 \mathrm{~h}$ (about 2.0-2.5\%) (22). To increase oil yield, the DIC isolation process was carried out at higher processing pressures $(0.4$ and 0.6 MPa, Figures 4B and 4C). The yield increases with increasing number of cycles and pressure. In $6 \mathrm{~min}, 4$ cycles give a yield of $0.52 \%, 1.2 \%$ and $1.92 \%$ at $0.2 \mathrm{MPa}, 0.4 \mathrm{MPa}$ and $0.6 \mathrm{MPa}$, respectively.

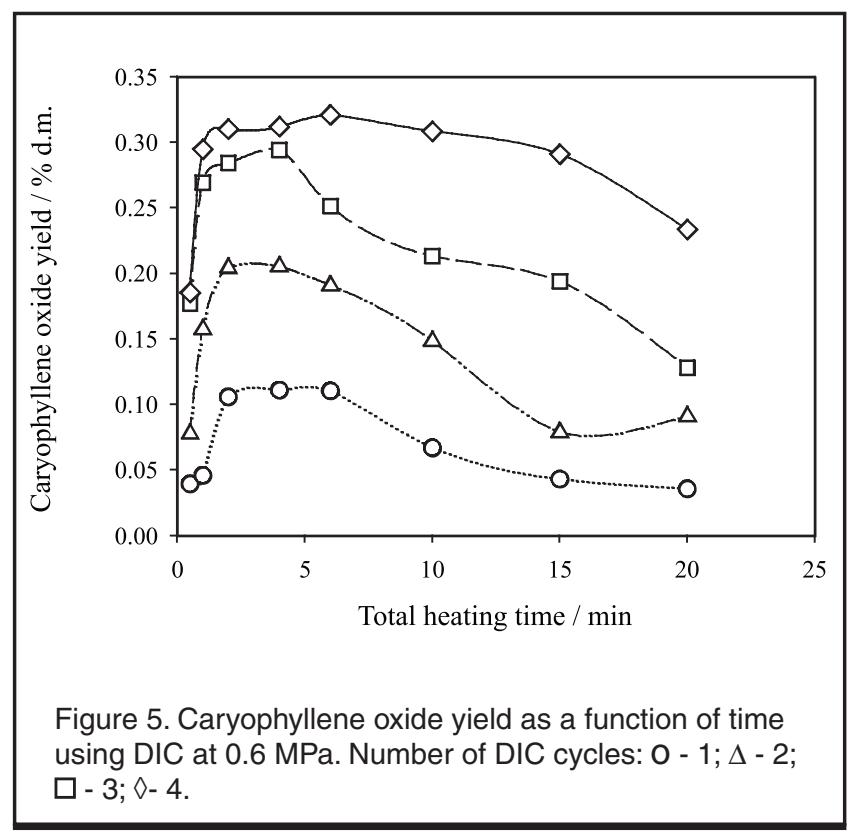

A longer heating time leads to oil break down (see Figure 5). After $6 \mathrm{~min}$, caryophyllene oxide probably breaks down to $\beta$-caryophyllene in the oil isolated by DIC at $0.6 \mathrm{MPa}\left(160^{\circ} \mathrm{C}\right)$. This observation is in agreement with Buccelatto's statement (4): exposure of flowers to a high temperature during long processing time in steam distillation leads to formation of $\beta$-caryophyllene from epoxy-dihydrocaryophyllene. The degradation of caryophyllene oxide increases with steam pressure and heating time $(13,23)$. The risk of oil degradation could be reduced by shortening the heating time. It should be noted that only a small gain in oil yield can be obtained during the time exceeding 6 min. Therefore, a total heating time of 6 min was maintained in the further study of the effect of the DIC cycle number and processing pressure on oil yield.

The oil yield as a function of the number of DIC cycles is shown in Figure 6. The oil yield increased significantly with the increasing processing pressure and DIC cycles until 8 cycles. An oil yield of $2.77 \%$ could be obtained at $0.6 \mathrm{MPa}$ with 8 cycles in 6 min.

The DIC treatment has a double effect. First, the vapor generated in the flowers during the expansion breaks and alveolates their structure and carries out the oil. At the beginning of the next cycle, more steam can penetrate into the alveolated bulk. Hence the bulk temperature is closer to the steam temperature. This results in more vapor being generated during the next pressure drop. The quantity of the liberated volatile compounds also increases. Naturally, there are limits of structure expansion and quantity of released compounds. The mass transfer is not controlled by the diffusion of volatile

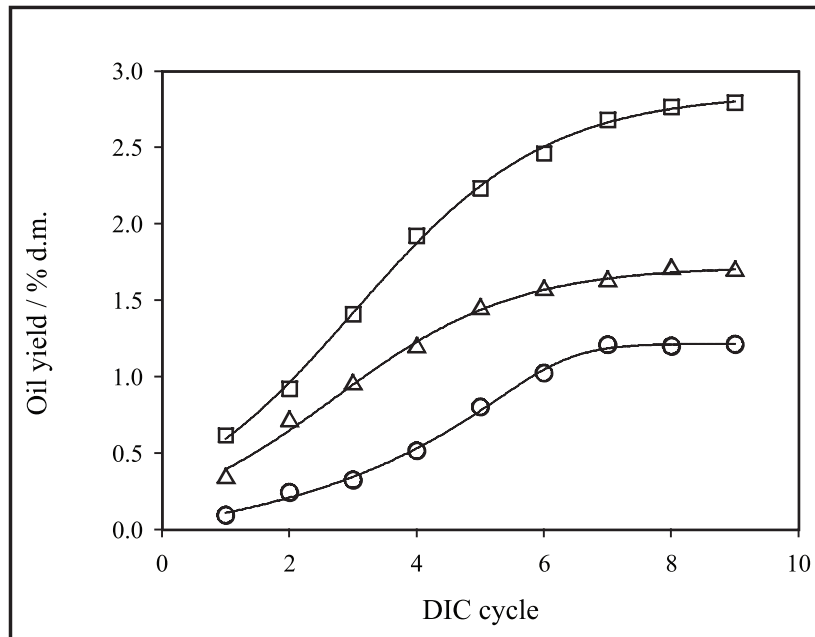

Figure 6. Effect of the number of DIC cycles and pressure on oil yield, $\mathrm{t}=6 \mathrm{~min}$. Pressure: $0-0.2 \mathrm{MPa} ; \Delta-0.4$ $\mathrm{MPa}$; $\square-0.6 \mathrm{MPa}$.

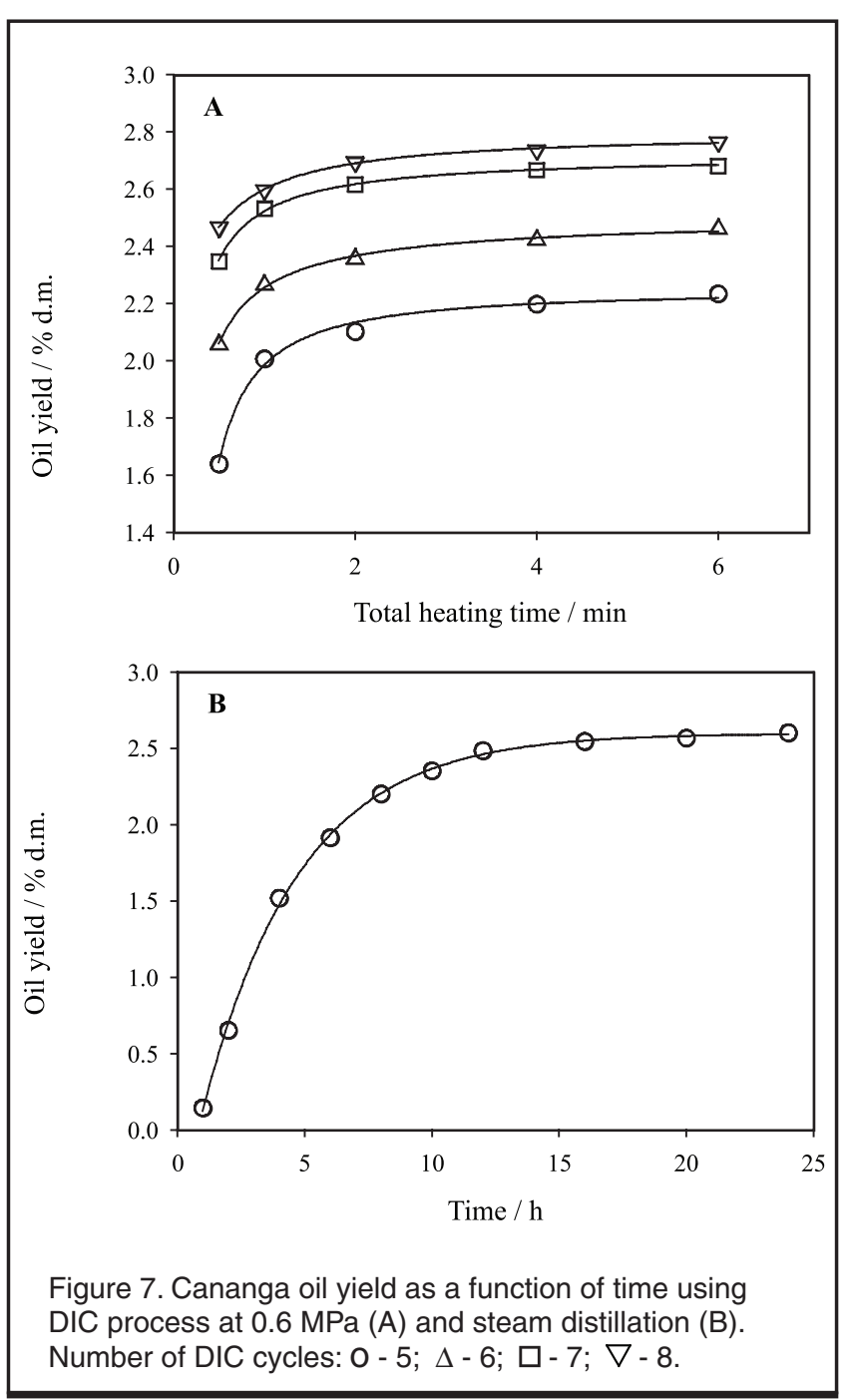


Table I. Chemical composition (\%) of Indonesian cananga oil obtained by steam distillation ( $24 \mathrm{~h}$ ) and DIC isolation (0.6 MPa, 8 cycles, $4 \mathrm{~min}$ ).

\begin{tabular}{|c|c|c|c|c|}
\hline R.I. & Compound & Type & SD & DIC \\
\hline 961 & benzaldehyde & LOC & 0.1 & 1.2 \\
\hline 985 & 6-methyl-5-hepten-2-one & LOC & 0.2 & 0.2 \\
\hline 1032 & benzyl alcohol & LOC & 0.1 & 5.5 \\
\hline 1074 & cis-linalool oxide (furanoid form) & LOC & 0.1 & 0.6 \\
\hline 1088 & trans-linalool oxide (furanoid form) & LOC & 0.1 & 0.3 \\
\hline 1097 & linalool & LOC & 2.2 & 1.4 \\
\hline 1100 & $\alpha$-pinene oxide & LOC & 0.2 & 0.2 \\
\hline 1163 & benzyl acetate & LOC & 0.1 & 0.3 \\
\hline 1240 & neral & LOC & 0.0 & 0.1 \\
\hline 1255 & geraniol & LOC & 1.6 & 2.4 \\
\hline 1270 & geranial & LOC & 0.1 & 0.3 \\
\hline 1351 & $\alpha$-cubebene & $S$ & 0.2 & 0.2 \\
\hline 1356 & eugenol & LOC & 0.3 & 0.5 \\
\hline 1376 & $\alpha$-copaene & $S$ & 1.3 & 1.0 \\
\hline 1383 & geranyl acetate & LOC & 0.2 & 0.3 \\
\hline 1390 & $\beta$-cubebene & $S$ & 0.2 & 0.2 \\
\hline 1391 & $\beta$-elemene & $S$ & 0.3 & 0.0 \\
\hline 1401 & methyl eugenol & LOC & 0.5 & 0.4 \\
\hline 1418 & $\beta$-caryophyllene & $S$ & 18.2 & 9.9 \\
\hline 1433 & $\gamma$-elemene & $S$ & 0.4 & 0.2 \\
\hline 1443 & $(Z)-\beta$-farnesene & $\mathrm{S}$ & 0.3 & 0.1 \\
\hline 1454 & $\alpha$-humulene & $S$ & 6.5 & 3.8 \\
\hline 1458 & $(E)-\beta$-farnesene & $S$ & 0.7 & 0.9 \\
\hline 1461 & allo-aromadendrene & $\mathrm{S}$ & 0.3 & 0.1 \\
\hline 1477 & $\gamma$-muurolene & $S$ & 0.5 & 0.4 \\
\hline 1480 & germacrene D & $\mathrm{S}$ & 2.0 & 1.1 \\
\hline 1490 & cis- $\beta$-guaiene & $\mathrm{S}$ & 0.4 & 0.2 \\
\hline 1499 & $\alpha$-muurolene & $\mathrm{S}$ & 0.6 & 0.5 \\
\hline 1500 & trans- $\beta$-guaiene & $\mathrm{S}$ & 4.3 & 3.8 \\
\hline 1509 & $\beta$-bisabolene & $\mathrm{S}$ & 0.1 & 0.1 \\
\hline 1513 & $\gamma$-cadinene & $\mathrm{S}$ & 0.3 & 0.1 \\
\hline 1526 & $\beta$-cadinene & $\mathrm{S}$ & 1.5 & 1.0 \\
\hline 1529 & cis-calamenene $+\delta$-cadinene & $S$ & 0.9 & 0.7 \\
\hline 1532 & trans-calamenene & $S$ & 0.2 & 0.1 \\
\hline 1533 & cadina-1,4-diene & $\mathrm{S}$ & 0.4 & 0.3 \\
\hline 1534 & (Z)-nerolidol & $\mathrm{HOC}$ & 1.1 & 1.1 \\
\hline 1536 & dihydro-eugenol acetate & $\mathrm{HOC}$ & 0.6 & 0.6 \\
\hline 1549 & elemol & $\mathrm{HOC}$ & 0.1 & 0.2 \\
\hline 1564 & (E)-nerolidol & $\mathrm{HOC}$ & 0.1 & 0.1 \\
\hline 1570 & (Z)-3-hexenyl benzoate & $\mathrm{HOC}$ & 0.4 & 0.3 \\
\hline 1581 & caryophyllene oxide & $\mathrm{HOC}$ & 13.8 & 20.1 \\
\hline 1583 & globulol & $\mathrm{HOC}$ & 0.8 & 0.7 \\
\hline 1596 & cedrol & $\mathrm{HOC}$ & 0.5 & 0.4 \\
\hline 1606 & humulene epoxide II & $\mathrm{HOC}$ & 4.0 & 1.2 \\
\hline 1640 & epi- $\alpha-$ cadinol & $\mathrm{HOC}$ & 1.0 & 0.6 \\
\hline 1642 & cubenol & $\mathrm{HOC}$ & 0.4 & 0.3 \\
\hline 1645 & $\alpha-$ muurolol & $\mathrm{HOC}$ & 0.9 & 0.5 \\
\hline 1649 & $\beta$-eudesmol & $\mathrm{HOC}$ & 1.1 & 0.8 \\
\hline 1652 & $\alpha$-eudesmol & $\mathrm{HOC}$ & 1.6 & 1.6 \\
\hline 1653 & $\alpha$-cadinol & $\mathrm{HOC}$ & 0.7 & 0.5 \\
\hline 1658 & 7-epi- $\alpha$-eudesmol & $\mathrm{HOC}$ & 0.8 & 0.7 \\
\hline 1671 & $\beta$-bisabolol & $\mathrm{HOC}$ & 2.4 & 2.5 \\
\hline 1672 & aromadendrene oxide-(1) & $\mathrm{HOC}$ & 0.7 & 0.6 \\
\hline 1678 & aromadendrene oxide-(2) & $\mathrm{HOC}$ & 2.7 & 3.4 \\
\hline 1679 & (Z)- $\alpha$-santalol & $\mathrm{HOC}$ & 1.3 & 0.9 \\
\hline 1688 & 8-cedren-13-ol & $\mathrm{HOC}$ & 1.8 & 0.7 \\
\hline 1722 & $(E, E)$-farnesol & $\mathrm{HOC}$ & 0.1 & 5.0 \\
\hline 1762 & benzyl benzoate & $\mathrm{HOC}$ & 7.9 & 6.5 \\
\hline 1843 & $(E, E)$-farnesyl acetate & $\mathrm{HOC}$ & 0.8 & 0.6 \\
\hline 1863 & benzyl salicylate & $\mathrm{HOC}$ & 1.5 & 1.6 \\
\hline 1949 & geranyl benzoate & $\mathrm{HOC}$ & 0.8 & 0.6 \\
\hline
\end{tabular}

R.I: retention indices relative to $\mathrm{C}_{8}-\mathrm{C}_{32} n$-alkanes; LOC: light oxygenated compounds; S: sesquiterpenes; HOC: heavy oxygenated compounds components, which is the case of the conventional isolation process by steam distillation. The isolation kinetics also depends on the bonds between compounds and the structure.

It is interesting to note that the maximum yield of cananga oil was obtained with 8 cycles at $0.6 \mathrm{MPa}$ in $6 \mathrm{~min}$. Rezzoug et al. (24) found that 2 cycles at $0.3 \mathrm{MPa}$ in $10 \mathrm{~min}$ were sufficient for the rosemary oil isolation. It seems that the structure of Indonesian cananga flowers, namely secretory cells, is very complex and rigid. However, a more detailed study of the structure is necessary.

DIC isolation is a rapid process in comparison with steam distillation (see Figure 7). DIC can already isolate between $60 \%$ and $85 \%$ of the maximum oil in $30 \mathrm{~s}$. Steam distillation requires $8 \mathrm{~h}$ to isolate $85 \%$. A yield of $2.45 \%$ can be obtained either using 8 cycles, $0.6 \mathrm{MPa}$ DIC isolation during $30 \mathrm{~s}$ or $12 \mathrm{~h}$ steam distillation. From the rapidity of DIC isolation it can be judged that this process is based only on the auto-vaporization of volatile molecules from a modified structure.

The high energy of the instantaneous auto-vaporization creates a mixture which condenses into a very stable oil-inwater emulsion. The classical methods like decantation or centrifugation are not efficient for the separation of this emulsion. The ability of membrane ultrafiltration to separate oil-in water emulsions has been tested successfully (25-27).

Oil composition: Besides the yield, the performance of the isolation methods is appreciated according to the oil quality. A comparison of the chemical composition of the cananga oils obtained by DIC and steam distillation is presented in Table I. The gas chromatograms of cananga oil obtained from dry flowers by DIC and SD techniques are shown in Figure 8.

Only well identified compounds, which constituted about $90 \%$ of the oil, are presented in Table I. Several non-identified peaks, which have never been reported in ylang-ylang and cananga oils, were also found (28-31). It seems that the corresponding compounds were artifacts of flower drying. The chemical composition of our cananga oil was also different from that reported for fresh flowers (4). However, oil isolations from fresh flowers could not be carried out at this stage of the study because of the long distance between our laboratory and flower source.

The compounds were grouped into three families in order to facilitate evaluation of the effect of the isolation method on the chemical composition of the isolated oils (see Table II). Sesquiterpenes hydrocarbons are less valuable than oxygenated compounds in terms of their contribution to the fragrance of the oil. The major sesquiterpenes in the cananga oil, namely $\beta$-caryophyllene and cadinene, contribute to the woody character, whereas the others components of sesquiterpenes are

Table II. Grouped compounds and yield of cananga oil obtained by steam distillation $(24 \mathrm{~h})$ and DIC isolation $(0.6 \mathrm{MPa}, 8$ cycles, $4 \mathrm{~min})$.

\begin{tabular}{lrr}
\hline Compounds & SD & DIC \\
\hline Light oxygenated compounds (\%) & 5.8 & 13.8 \\
Sesquiterpenes (\%) & 39.8 & 24.8 \\
Heavy oxygenated compounds (\%) & 53.4 & 60.1 \\
Oil yield (\% d.m.) & 2.6 & 2.7 \\
\hline
\end{tabular}




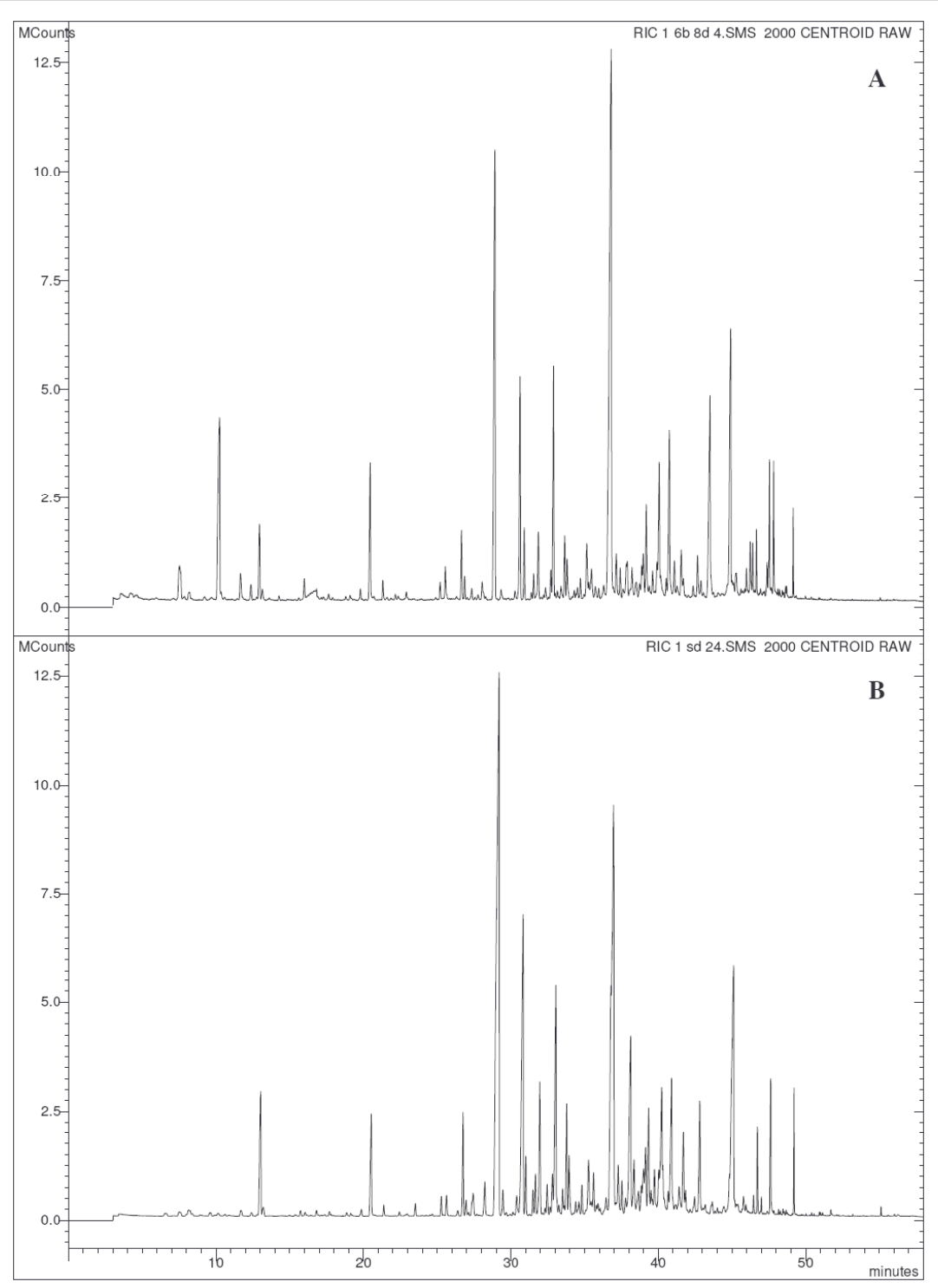

Figure 8. Comparison of gas chromatograms of Indonesian cananga oil obtained by DIC at $0.6 \mathrm{MPa}, 8$ cycles, 4 min (A) and SD during $24 \mathrm{~h}(\mathrm{~B})$.

not very important odor contributors (4). On the other hand, the both oxygenated compounds are highly odoriferous and the most valuable. Buccelatto (4) reported that the oxygenated compounds (alcohols, esters, ethers, phenols and aldehydes) provide the medicinal, floral, spicy/balsamic and fruity nuance to the odor profile. The complex character of cananga oil is due to a combination of floral, spicy, balsamic, fruity, woody and medicinal notes. The quality of oil increases with the content of the oxygenated compounds. A substantially higher amount of oxygenated compounds and a lower amount of sesquiterpenes hydrocarbons were present in the cananga oil isolated by DIC in comparison with steam distillation (see Table II). The DIC process provided a better quality of cananga oil than steam distillation.

A lower content of sesquiterpenes in the DIC oil is probably due to the reduction of thermal degradation. Steam distillation uses a large quantity of water at a high temperature for a long time. Water as a polar solvent could accelerate hydrolytic, trans-esterification or oxidation reactions of other compounds into sesquiterpenes.

The DIC oil was rich in HOC (16.46 mg HOC/g dry mass) with a high content of caryophyllene oxide $(5.51 \mathrm{mg})$, followed by benzyl benzoate (1.78 mg), (E,E)-farnesol (1.36 mg), aromadendrene oxide-(2) (0.92 mg), $\beta$-bisabolol (0.69 mg) and benzyl salicylate $(0.45 \mathrm{mg})$. The second most abundant compound group were sesquiterpenes (6.80 mg sesquiterpenes/g dry mass) which contain $\beta$-caryophyllene $(2.70 \mathrm{mg}), \alpha$-humulene (1.04 $\mathrm{mg})$, trans- $\beta$-guaiene (1.04 mg), germacrene D $(0.31 \mathrm{mg})$ and $\beta$-cadinene $(0.27 \mathrm{mg})$. The concentration of LOC was low $(3.77$ $\mathrm{mg}$ LOC/g dry flowers), with an important amount of benzyl alcohol (1.75 mg), geraniol (0.66 mg), linalool $(0.38 \mathrm{mg})$ and benzaldehyde $(0.33 \mathrm{mg})$.

The steam-distilled oil was less rich in HOC $(13.87 \mathrm{mg}$ HOC/g dry mass) which contained caryophyllene oxide (3.58 
mg), benzyl benzoate (2.05 mg), humulene epoxide II (1.04 mg), $\beta$-bisabolol (0.63 mg), aromadendrene oxide-(2) (0.71 $\mathrm{mg})$ and benzyl salicylate $(0.39 \mathrm{mg})$. The second most abundant group were sesquiterpenes (10.34 mg sesquiterpenes/g dry mass) with a high content of $\beta$-caryophyllene $(4.73 \mathrm{mg})$, followed by $\alpha$-humulene (1.70 mg), trans- $\beta$-guaiene (1.10 $\mathrm{mg})$, germacrene $\mathrm{D}(0.53 \mathrm{mg})$ and $\beta$-cadinene $(0.39 \mathrm{mg})$. The concentration of LOC was low (1.49 mg LOC/g dry mass), with important amount of linalool $(0.56 \mathrm{mg})$ and geraniol (0.40 mg).

Analysis of residual flower oil: For a better understanding of the DIC isolation mechanism, a quantitative comparative study of the residual and reference oil was realized. These oils were obtained by the extraction of the DIC treated ( 8 cycles, $4 \mathrm{~min}, 0.2$ and $0.6 \mathrm{MPa}$ ) and non-treated flowers with chloroform in $6 \mathrm{~h}$. The gas chromatograms are

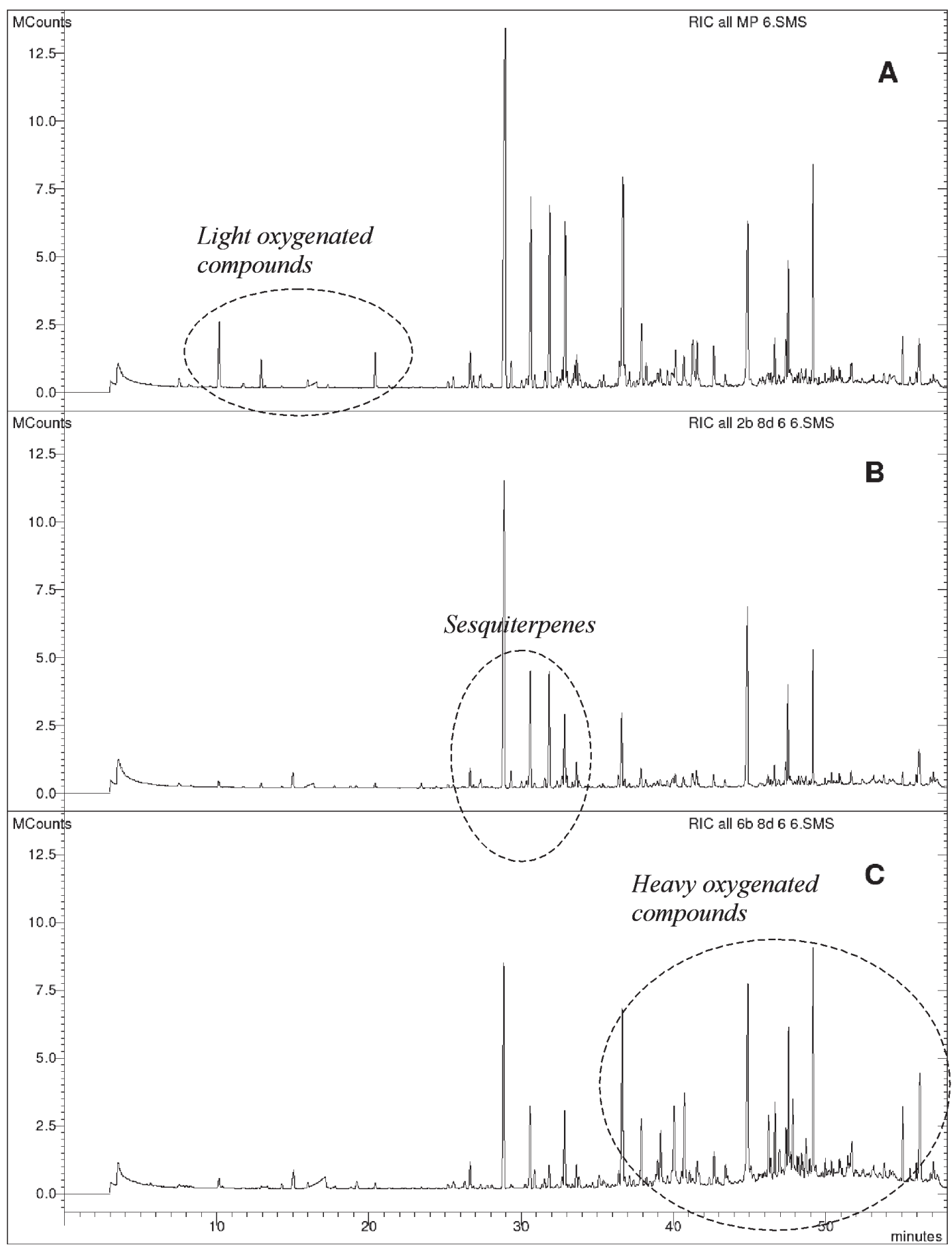

Figure 9. Gas chromatograms of cananga volatiles obtained by chloroform extraction in $6 \mathrm{~h}$ from: non-treated flowers (A); DIC treated flowers at $0.2 \mathrm{MPa}, 8$ cycles, $4 \mathrm{~min}(\mathrm{~B})$ and $0.6 \mathrm{MPa}, 8$ cycles, $4 \mathrm{~min}(\mathrm{C})$. 
shown in Figure 9 and their compositions in form of grouped compounds in Table III.

The compounds availability is shown in Table IV. The DIC treatment results in a high total availability of LOC and HOC and low total availability of sesquiterpenes. Such an oil composition is appreciated especially in perfumery.

Two DIC effects on the isolation process can be distinguished. There is the isolation of LOC, sesquiterpenes and

Table III. Yield and grouped compounds of volatiles in the reference oil (non-treated flowers) and residual oil (8 DIC cycles, $4 \mathrm{~min}$ ).

\begin{tabular}{lccc}
\hline Compounds & Reference oil & \multicolumn{2}{c}{ Residual oil } \\
& & $\mathbf{0 . 2} \mathbf{~ M P a}$ & $\mathbf{0 . 6} \mathbf{~ M P a}$ \\
\hline Light oxygenated compounds (\%) & 4.9 & 2.1 & 1.3 \\
Sesquiterpenes (\%) & 41.7 & 50.0 & 13.3 \\
Heavy oxygenated compounds (\%) & 53.3 & 46.9 & 85.4 \\
Oil yield (\% d.m.) & 4.9 & 2.5 & 3.8 \\
\hline
\end{tabular}

a part of HOC by DIC (see Table III). It is explained by the liberation of the volatile compounds and less volatiles compounds due to the instantaneous vaporization. However at the same time the amount of HOC in the residual oil increased (see Table IV and Figures 9 and 10). Hence, the sum of HOC in the condensate and residual oil was greater than the amount found in the reference oil (see Figure 11). For example, an amount of $60.2 \%$ HOC was found in the

Table IV. Effect of DIC pressure (8 cycles, $4 \mathrm{~min}$ ) on the relative and total availability.

\begin{tabular}{lccc}
\hline & \multicolumn{2}{c}{$A_{i R}$} & $A_{i}$ \\
Compounds & $\mathbf{0 . 2} \mathbf{~ M P a}$ & $\mathbf{0 . 6} \mathbf{~ M P a}$ & $\mathbf{0 . 6} \mathbf{~ M P a}$ \\
\hline LOC & 0.22 & 0.21 & 1.82 \\
Sesquiterpenes & 0.61 & 0.25 & 0.59 \\
HOC & 0.44 & 1.24 & 1.88 \\
Oil yield & 0.50 & 0.78 & 1.35 \\
\hline LOC: light oxygenated compounds; HOC: heavy oxygenated compounds
\end{tabular}
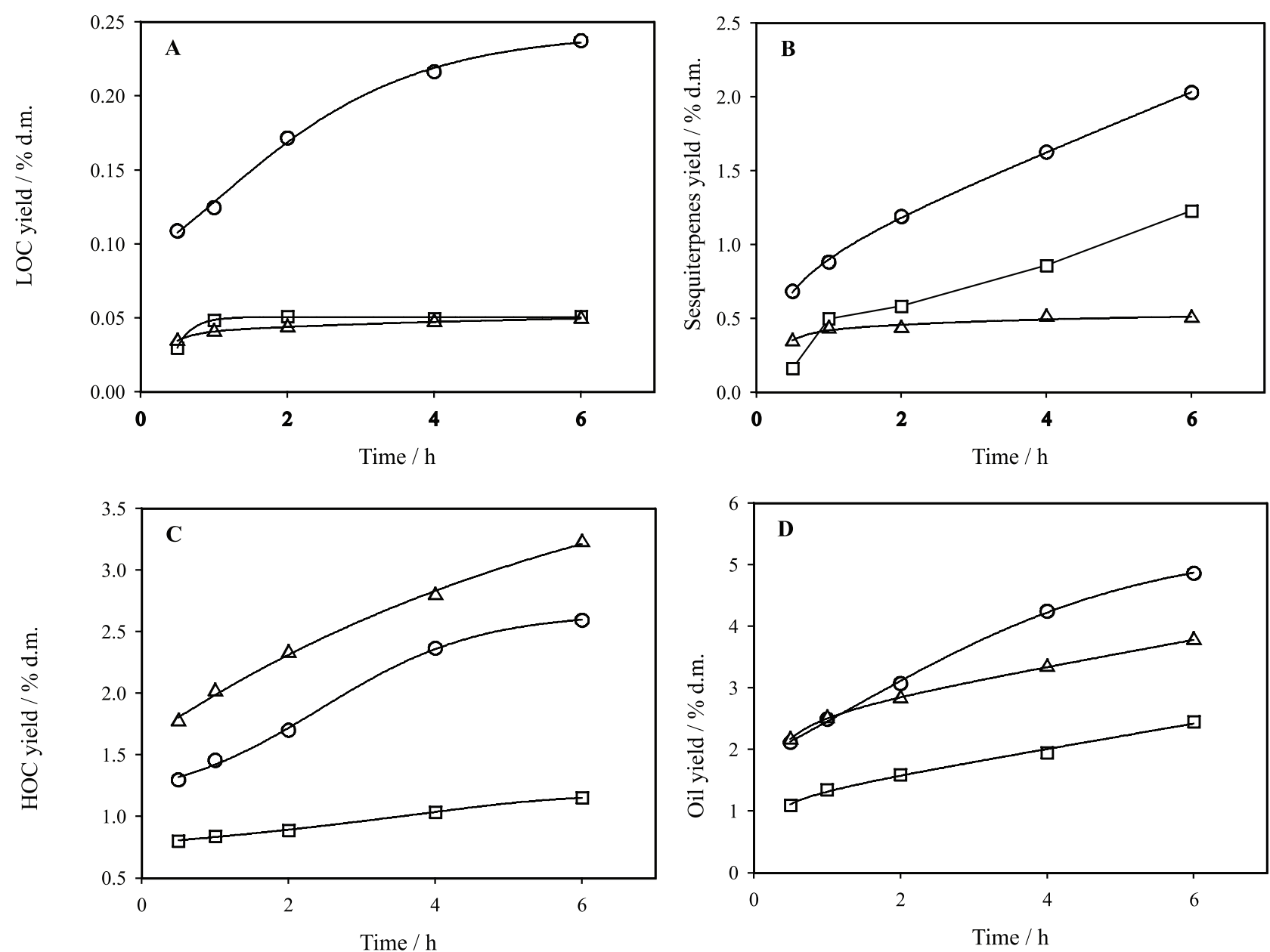

Figure 10. Yield of reference and residual oils and their grouped compounds as a function of time of chloroform extraction. (A) LOC, (B) sesquiterpenes, (C) HOC and (D) oil (total volatiles). O - reference oil (non-treated flowers), $\square$ - residual oil (DIC treated flowers with $0.2 \mathrm{MPa}), \Delta$ - residual oil $(0.6 \mathrm{MPa})$. 
condensate after the DIC treatment using 8 cycles at 0.6 MPa during 4 min, whereas the $A_{i R}$ value, which is greater than 1 (see Table IV), seemingly indicated that there was no isolation by auto-vaporization. The increasing total amount of HOC gained after the DIC treatment can be explained by the rising of its availability in the flowers.

A hypothesis can be made that HOC are located both in the exogenous and endogenous sites of the oil-containing glands, whereas LOC and sesquiterpenes mainly in the exogenous ones. The skin of the external glands is very thin and can be easily destroyed by low mechanical stresses, whereas for the rupture of the internal glands, stronger mechanical stresses are needed. The exogenous compounds and a part of endogenous compounds were isolated directly by auto-vaporization, while the compounds imprisoned in very endogenous site could not be carried away with steam. However, the DIC treatment modified the structure which made HOC more available for organic solvent extraction.

The breaking of cells by mechanical stresses induced by DIC need not be the only cause for the improvement of the organic solvent extraction, especially when dry material is used. During the drying process of plant tissues, a series of physical and chemical modifications takes place, which result in major differences between the fresh and dry tissue. The dried cells lose their capacity of diffusion and osmosis as a result of the cell wall and middle lamella desiccation. Organic solvent extraction is then a two stage process composed of i) the swelling dry material by a solvent and ii) the mass transfer of soluble constituents from the material to the solvent by diffusion and osmotic processes (32).

The chloroform extraction kinetics also manifests two DIC effects, namely isolation by auto-vaporization and availability increase due to the structure modification. The latter affect manifest itself especially at a higher pressure. The yield of oil and grouped compounds of the non-treated and DIC treated flowers ( 8 cycles, 4 min, 0.2 and $0.6 \mathrm{MPa}$ ) is shown in Figure 10 as a function of time. At the low pressure $0.2 \mathrm{MPa}$, DIC isolates mostly the exogenous compounds. The concentration of LOC, sesquiterpenes and HOC in the residual oil after $6 \mathrm{~h}$ was lower than in the reference oil. It is due to the phenomenon of the direct isolation by auto-vaporization. At a pressure of $0.6 \mathrm{MPa}$, the endogenous compounds become more available. Hence the concentration of HOC in the residual oil was greater than in the reference oil.

LOC are the most volatile compounds which are isolated easily by auto-vaporization. Their content in the residual oil was determined to be almost independent of pressure. This confirms that the majority of LOC was located in the exogenous site. The rest located in the endogenous site was extracted within $1 \mathrm{~h}$ (Figure 10A). The DIC oil contains more LOC than steam distillation does $(0.38 \%$ d.m. vs. $0.15 \%$ d.m.).

From the curves of residual sesquiterpenes (see Figure 10B), we can judge that the majority of these components are localized in a deeper site than LOC. The effects of $0.2 \mathrm{MPa}$ and the corresponding temperature of saturated steam are not sufficient for the complete liberation of sesquiterpenes. It should be noted that sesquiterpenes have a higher boiling point than LOC which slows down the DIC isolation at a low-pressure. A pressure of 0.6 MPa seems to have enough thermo-mechanical effects for the destruction of the deeper oil site.

It is impossible to release all compounds by auto-vaporization. There is always a quantity of LOC and sesquiterpenes in the residual flowers which can be extracted only with solvents such as chloroform. This solvent dissolves the cellular lipid fraction where the aromatics are imprisoned thereby releasing the LOC and sesquiterpenes.

The curves in Figure 10C prove our hypothesis about HOC location in both exogenous and endogenous sites of the oil-containing glands. The low yield after the DIC treatment at $0.2 \mathrm{MPa}$ means that the endogenous sites were not opened. The yield after the treatment at $0.6 \mathrm{MPa}$, which is higher than that of the non-treated flowers, signifies that the oil of the endogenous sites was made available.

The results on availability of cananga oil obtained by different isolation techniques are shown in Figure 11. The oil yield of the classical isolation methods is lower than that using the DIC treatment. The classical methods cannot isolate the totality of the oil. A similar increase in the availability of flavonoids in apples and onion by the DIC treatment was reported by El Rifai et al. (33).

The micrographs of the cross sections of the non-treated and DIC treated flowers are shown in Figure 12. The structure of non-treated flowers is compact with alveoli of several $\mu \mathrm{m}$ (see Figure 12A). The DIC treated flowers have larger alveoli with dimensions depending on the processing parameters. The vapor generated by the instantaneous auto-vaporization of volatiles and water induces the blowing and rupture of cell walls. The alveolation degree increases with the pressure and number of cycles. Such structures facilitate the liberation and vaporization of molecules (LOC, sesquiterpenes and HOC) and increase the availability of the residual HOC to solvent extraction from the endogenous site of the glands.

Heavy oxygenated compounds (HOC) and sesquiterpenes were the main components of the Indonesian cananga oil but their relative amount depended on the isolation method. The DIC process efficiently isolated the oil from cananga flowers. The optimum oil yield was obtained with eight cycles at a steam pressure of $0.6 \mathrm{MPa}$ and the total heating time $4 \mathrm{~min}$. A similar yield was obtained in $24 \mathrm{~h}$ using steam distillation. The DIC oil contained more light and heavy oxygenated components than did the steam distilled oil. In contrast, the content of less valuable sesquiterpenes was lower. The DIC treatment increased the availability of heavy oxygenated compounds in the flowers. The sum of HOC in the DIC oil and residual oil was greater than the HOC content in the reference oil. The degradation of caryophyllene oxide appeared to start at a heating time of 6 min. The structure of the flowers was the more porous the higher pressure and number of DIC cycles. The DIC process can be also used as a pre-treatment for improvement in the isolation of nonvolatiles compounds.

\section{References}

1. T.J. Hsieh, F.R. Chang and Y.C. Wu, The constituents of Cananga odorata J. Chin. Chem. Soc., 46, 607-611 (1999). 


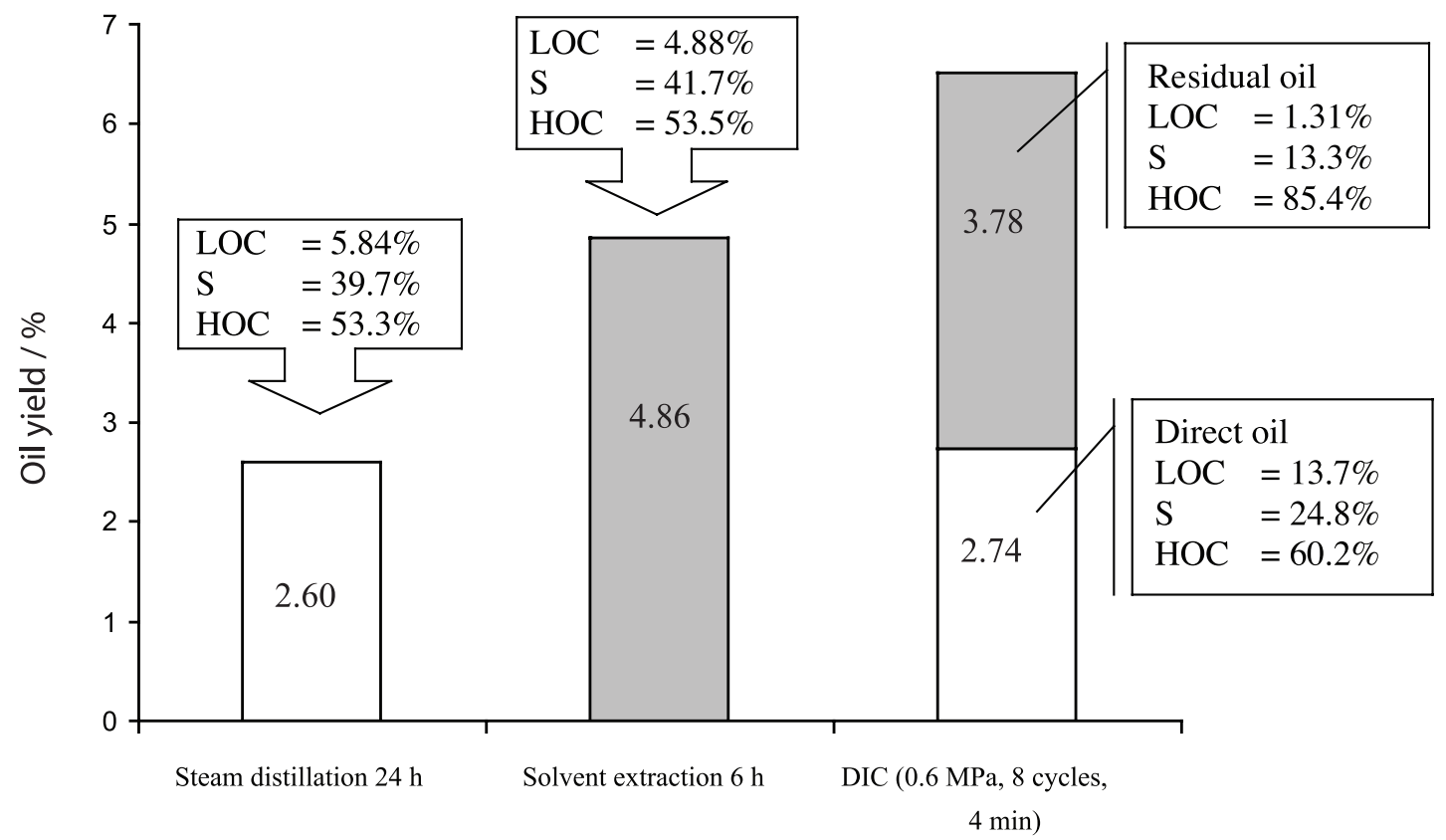

Figure 11. Yield of cananga oil by different isolation techniques.

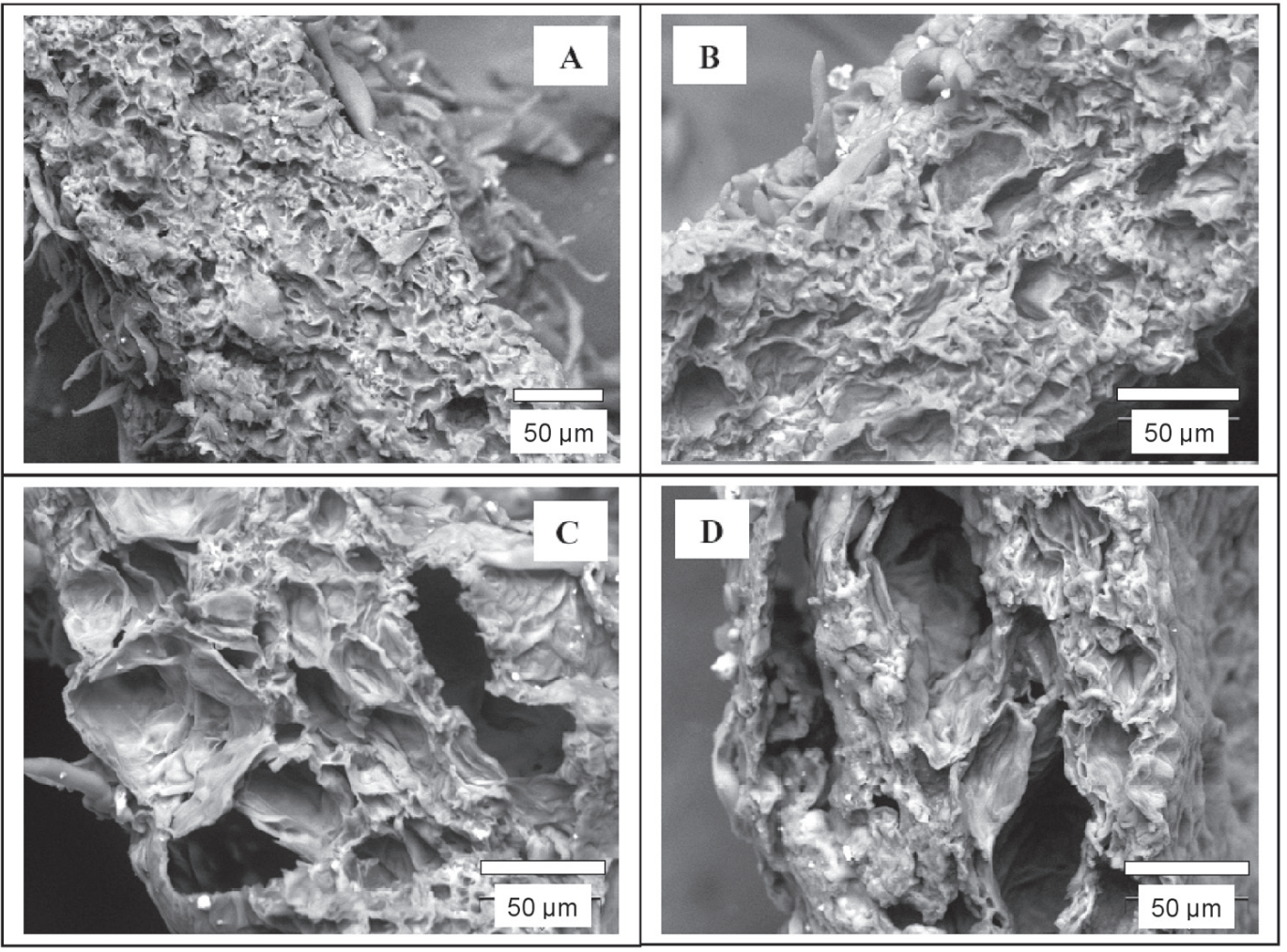

Figure 12. Micrographs of non-treated flowers (A) and DIC treated flowers at $0.2 \mathrm{MPa}, 1 \mathrm{cycle}, 10 \mathrm{~min}(\mathrm{~B}), 0.6 \mathrm{MPa}, 5 \mathrm{cycles}$, $4.4 \mathrm{~min}(\mathrm{C})$, and $0.6 \mathrm{MPa}, 9$ cycles, $10 \mathrm{~min}(\mathrm{D})$. 
2. K.Y. Orabi and A.M. Clark, Characterization of the major metabolite of sampangine in rats. J. Nat. Prod., 63, 396-398 (2000).

3. T.J. Hsieh, F.R. Chang, C.Y. Chia, Y.C. Chen, F.H. Chiu and C.Y. Wu, Cytotoxic constituents of the fruits of Cananga odorata. J. Nat. Prod., 64, 616-619 (2001).

4. F. Buccellato, Ylang survey. Perfum. Flavor., 7 (4), 9-13 (1982).

5. EM. Gaydou, R. Randriamiharisoa, and J.P. Bianchini, Composition of the essential oil of ylang-ylang (Cananga odorata Hook Fil. et Thomson forma genuina) from Madagascar. J. Agric. Food Chem., 34, 481-487 (1986).

6. J. Valnet, Aromathérapie, $11^{\mathrm{ème}}$ ed. Maloine, Paris, France (1990).

7. S.E. Lee, Biochemical mechanisms conferring cross-resistance to fumigant toxicities of essential oils in a chlorpyrifos-methyl resistant strain of Oryzaephilus surinamensis L. (Coleoptera: Silvanidae). J. Stored Prod. Res., 38, 167-166 (2002).

8. F. Gaspar, R. Santos and M.B. King, Disruption of glandular trichomes with compressed $\mathrm{CO}_{2}$ : alternative matrix pre-treatment for $\mathrm{CO}_{2}$ extraction of essential oils. J. Supercrit. Fluids, 21, 11-22 (2001).

9. M.D. Luque de Castro, M.M. Jiménez-Carmona and V. Fernández-Pérez, Towards more rational techniques for the isolation of valuable essential oils from plants. Trends Anal. Chem., 18, 708-716 (1999).

10. S.A. Rezzoug, N. Louka and K. Allaf, Effect of the main processing parameters of the Instantaneous Controlled Pressure Drop process on oil isolation from rosemary leaves. Kinetics aspects. J. Essent. Oil Res., 12, 336-344 (2000).

11. H.Mellouk, G. Naji and K. Allaf, Etude de l'extraction des huiles essentielles de baies de Genievre par Détente Instantanée Contrôlée DIC comparée à l'entraînement à la vapeur. In: Proceedings de $16^{\text {es }}$ Rencontres Scientifiques et Technologiques des Industries Alimentaires (Agoral). pp. 265-269 Nantes, France (2004).

12. M. Kristiawan, V. Sobolik and K. Allaf, Yield and Composition of Indonesian Cananga Oil Obtained by Steam Distillation and Organic Solvent Extraction. Int. J. Food Eng., submitted (2008).

13. M. Kristiawan, Traitement thermo-mécanique des fleurs d'ylang-ylang indonésienne par Détente Instantanée Contrôlée en vue de l'extraction de composés volatiles. Ph.D. Thesis, Université de La Rochelle, France (2006).

14. N. Louka and K. Allaf, Expansion ratio and color improvement of dried vegetables texturized by a new process "Controlled Sudden Decompression to the vacuum". Application to potatoes, carrots and onions. J. Food Eng., 65, 233-243 (2004).

15. J. Cai, B. Liu, P. Ling and Q. Su, Analysis of free and bound volatiles by gas chromatography and gas chromatography/mass spectrometry in uncased and cased tobaccos. J. Chromatogr. A, 947, 267-275 (2002).

16. A. Djerrari, Influence du mode d'extraction et des conditions de conservation sur la composition des huiles essentielles de thym et de basilic. Ph.D. Thesis, Université des Sciences et Techniques du Languedoc, Montpellier, France (1983).
17. R.P. Adams, Identification of Essential Oil Components by Gas chromatography / Mass Spectroscopy. Allured Publishing Corp., Carol Stream, IL (1995).

18. S. Arctander, Perfume and Flavor Chemicals. Allured Publishing Corp., Carol Stream, IL (1994).

19. N.W. Davies, Gas chromatographic retention indices of monoterpenes and sesquiterpenes on methyl silicone and carbowax $20 \mathrm{M}$ phases. J. Chromatogr., 503, 1-24 (1990).

20. W. Jennings andT. Shibamoto, Qualitative Analysis of Flavor and Fragrance Volatiles by Glass Capillary Gas Chromatography. Academic Press, New York, NY (1980).

21. B.R. Rajeswara Rao, P.N. Kaul, K.V. Syamasundar and S. Ramesh, Chemical profiles of primary and secondary essential oils of palmarosa (Cymbopogon martinii (Roxb.) Wats var. motia Burk.). Ind. Crops Prod. 21, 121-127 (2005).

22. E. Guenther, The Essential Oils, Vol. 5, pp. 276-316, 381. Van Nostrand, Princeton, NJ (1952).

23. M. Kristiawan, V. Sobolik and K. Allaf, Isolation of Indonesian Cananga Oil by Instantaneous Controlled Pressure Drop. Influence of processing parameters on compound yields. J. Chem. Eng. Japan, 40, 1021-1029 (2007).

24. S.A. Rezzoug, M.W. Baghdadi, N. Louka, C. Boutekedjiret and K. Allaf, Study of anewextraction process: Controlled instantaneous decompression. Application to the extraction of essential oil from rosemary leaves. Flav. Fragr. J., 13, 251-258 (1998).

25. T.C. Arnot, R.W. Field, and A.B. Koltuniewicz, Cross-flow and dead-end microfiltration of oily-water emulsions: Part II. Mechanisms and modelling of flux decline. J. Membrane Sci., 169, 1-15 (2000).

26. J.M. Benito, S. Ebel, B. Gutierrez, C. Pazos and J. Coca, Ultrafiltration of a waste emulsified cutting oil using organic membranes. Water Air Soil Pollut., 128, 181-195 (2001).

27. S.M. Mahdi and R.O. Skold, Experimental study of membrane filtration for the recycling of synthetic water-based metal working fluids. Tribol. Internat. 24, 389-395 (1991).

28. B.M. Lawrence, Progress in Essential Oils. Perfum. Flavor., 11 (5), 118-124 (1986).

29. B.M. Lawrence, Progress in Essential Oils. Perfum. Flavor., 14 (3), 79-80 (1989).

30. B.M. Lawrence, Progress in Essential Oils. Perfum. Flavor., 20 (2), 57-59 (1995).

31. B. M. Lawrence, Progress in Essential Oils. Perfum. Flavor., 31 (9), 65-67 (2006).

32. M. Vinatoru, An overview of ultrasonically assisted extraction of bioactive principles from herbs. Ultrason. Sonochem., 8, 303-313 (2001).

33. M. El-Rifaï, L. Ebner and K. Allaf, Influence du traitement hydro-thermomécanique sur la disponibilité des bioflavanoïdées dans les fruits et les legumes. In: Proceedings de $16^{\text {es }}$ Rencontres Scientifiques et Technologiques des Industries Alimentaires (Agoral). pp 40-47 Nantes, France (2004). 